\begin{tabular}{ll}
\hline 論 & 説 \\
\hline
\end{tabular}

頭頸部癌の最近の化学療法

佃守

\title{
Recent Developments in Chemotherapy for the Treatment of Head and Neck Cancer
}

\author{
Mamoru Tsukuda \\ (Yokohama City University, School of Medicine)
}

\begin{abstract}
Curative treatments for head and neck carcinomas consists of surgery and/or radiotherapy. However, standard treatment alone is less successful in cases of advanced head and neck carcinomas. With the development of cisplatin (CDDP), the efficacy of chemotherapy, including CDDP therapy, has increased markedly in the treatment of head and neck cancer. Accordingly, neo-adjuvant chemotherapy has been applied in cases of advanced carcinoma. Previous studies have demonstrated that this type of chemotherapy is efficacious in patients with a complete response (CR), especially a pathological CR, in terms of the preservation of primary organs and overall survival following chemotherapy. Therefore, the development of an intensive chemotherapy regimen showing a high CR rate is necessary. Recent developments in chemotherapy, including CDDP and 5 -fluorouracil treatment, described in the previous reports were reviewed and our studies were summarized.
\end{abstract}

Key words : chemotherapy, head and neck cancer, CDDP plus 5-fluorouracil

はじめに

頭頸部癌の大部分は扁平上皮癌で，ある程度放射線に 感受性があるため早期癌あるいは解剖学的に手術のでき ない上咽頭癌などに根治治療として放射線治療が繁用さ れている. また一方, 手術が根治治療の 1 つであること は言らまでもない。しかしこうした放射線治療, 手術 だけの標準的治療だけでは頭頸部進行癌の予後は覀く, 第 3 , 第 4 の治療法として化学療法, 免疫療法の工夫が 行われ，予後の向上が図られてきた.

頭頸部扁平上皮癌に対する化学療法は cisplatin (CDDP) の出現以後飛躍的に進歩した. この薬剤単独で は奏効率はそれほど高くないが，ほかの薬剤を併用する ことによって奏効率が向上することが判明している.し
かし奏効率は高いものの，この CDDPを含む多剂併用 療法がはたしてどこまで予後に貢献してきたかは未だ十 分には解明されていない. CDDP 出現後のこの約 20 年 間に判ったことは, partial response (PR)や no change (NC) 例ではその予後への効果は期待できず, 結局は放 射線や手術などの根治治療に期待せざるを得ないといら 事実である. 一方 clinical CR 症例, とくに histological CR が得られた症例では長期予後が明らかに良いことは 判明している1). こうした経緯から現状では CR 率の高 い化学療法の考案に期待がかかっている.

\section{CDDP を含む化学療法の変遷}

化学療法は CDDP の出現以前は methotrexate (MTX), 
bleomycin (BLM), BLM の誘導体である peplomycin (PEP) を中心とした併用療法が，手術が不可能な進行癌， 再発癌で検討が加えられていた。 しかしその効果の持続 期間が短く，はたして延命，予後の向上に有用か否かは 不明瞭であった。唯一上䫇洞癌に対して放射線増感剤と して 5-fluorouracil (5-FU) などを動注し放射線治療を行 い，手術と組み合わせたいわゆる 3 者併用療法に放射線 増感剂として用いられていた。

現在 CDDP あるいはその誘導体を含む化学療法の用 い方は再発癌に対する治療を除くと, 手術や放射線治療 による根治治療に先行して用いる neo-adjuvant chemotherapy (induction chemotherapy), 放射線治療に増感剤 として用いる方法, また根治治療の強化療法 (adjuvant

表 1 われわれの施設での頭頸部扁平上皮癌に対する 化学療法のレジメ

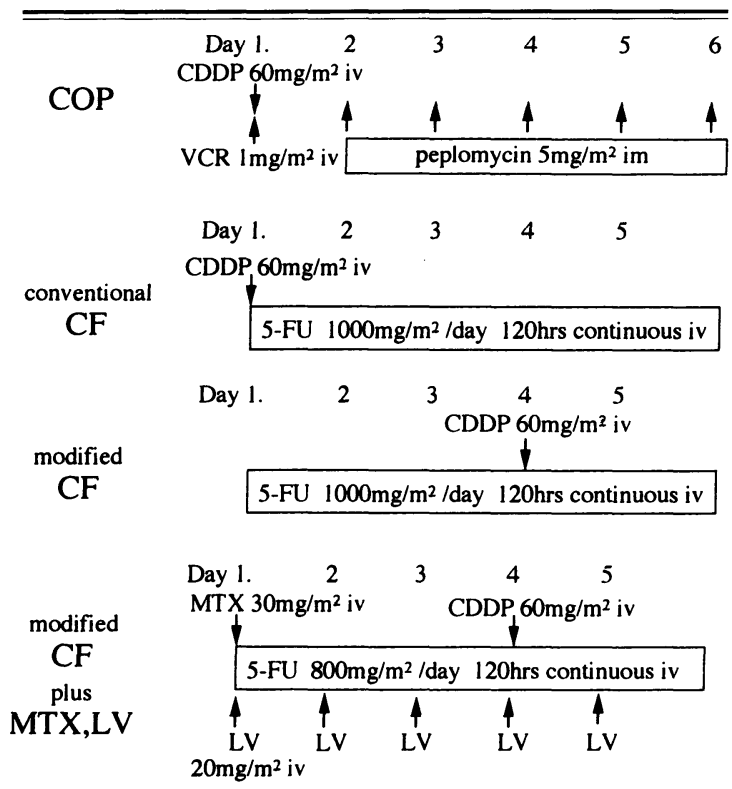

chemotherapy)に大別される

CDDP を含を多剤併用療法は，とくに neo-adjuvant chemotherapy としてその効果が検討されてきた。当初， CDDP そ BLM, vincristine (VCR) の COB 療法2) あるい は本邦では CDDP に PEP の CP 療法3)さらに VCR を 加之た COP 療法が施行されていた4)。しかし，CDDP に 5-FUを長時間持続で併用する CF 療法が，CR 率が 高いことから（表 1，2），主にこの CF 療法が1980年代 初旬から頭頸部癌では主流になっている. CF 療法が臨 床応用され始めた時点では CDDP と 5-FU 併用による 相乗効果の機序の解明は行われず，経験的に 5-FU が頭 頸部癌に有用であることから CDDP と併用されたに過 ぎない。

一方症例数は少ないものの頭頸部腺系癌の腫瘍には卵 巣癌に繁用されている CDDP, doxorubicin, cyclophosphamide 併用の CAP 療法が用いられてきた．扁平 上皮癌に対する CDDP を含む多剤併用療法と比較して 奏効率, $\mathrm{CR}$ 率とも低いものの，ある程度の効果は CAP 療法で得られている5)。 しかし，もともと放射線治 療や化学療法に対する期待が少なく, 手術が主体の頭頸 部腺系癌に対しては，CAP 療法以上の奏効性をもつレ ジメは今のところ認められない。

CDDP を含む化学療法の奏効性に関して頭頸部扁平 上皮癌を組織学的に高，中，低分化型に分けて検討し， 当初は低分化型に対して有効性が高いとの報告があった が，現在のところは特別に分化度と奏効性は関係ないと の報告が多い，われわれが上咽頭癌を含む未治療進行咽 頭扁平上皮癌 (stage III, N) で行った検討でも，特別に 低分化型が奏効性が高いとの結果は得られていない。 CDDP を含む化学療法は一般的には老年者より若年者, また男性より女性の方が奏効性は高いが有意な差ではな い.

表 $2 \mathrm{COB}$ あるいは COP 療法と CF 療法の奏効率の比較

(文献 2, 4 より引用, 上段; $\mathrm{COB}: 2$ ュース, $\mathrm{CF}: 3$ ュース, 下段; $\mathrm{COP}, \mathrm{CF}$ ともに 2 コース)

\begin{tabular}{lccccc}
\hline \hline & $\begin{array}{c}\text { No. of } \\
\text { patients }\end{array}$ & \multicolumn{2}{c}{ Response (cases) } & Response rate & Complete response rate \\
CR & PR & CR + PR/total & $29 \%$ \\
\hline COB & 77 & 22 & 39 & $80 \%$ & $54 \%$ \\
CF & 61 & 33 & 24 & $93 \%$ & $10 \%$ \\
\hline COP & 41 & 4 & 27 & $76 \%$ & $16 \%$ \\
CF & 73 & 12 & 48 & $82 \%$ &
\end{tabular}


CDDP を含む化学療法を何コース行らかは重要な臨 床の課題である6). 効果のない化学療法を漫然と行らの は，副作用などから来る患者の負担を増すばかりではな く，予後を悪くするものと思われる．そこで咽頭癌で CR になる症例の 1 コース目の臨床効果を見たが， 1 コース目で PR 近くにならなければあとコースを重ねて も CRにはならないこと，また1コース目で PRになっ た症例と 2 コース目以降で PR になった症例の予後を比 較すると，明らかに 1 コース目でPRになった症例の予 後は良好であった（図 1 )。ささらにCDDPを含む化学療 法が NC あるいは progressive disease (PD) であった non-responder に限ると無効な化学療法を重ねることは 予後を逆に悪くする傾向も認められた（図 2 ).

CF 療法に話を戻すが，欧米では CDDPは $100 \mathrm{mg} /$ $\mathrm{m}^{2} /$ day が用いられているが本邦では $60 \sim 80 \mathrm{mg} / \mathrm{m}^{2}$ /day が主流で，5-FU の連続投与も当初は 1 日 $800 \mathrm{mg} /$

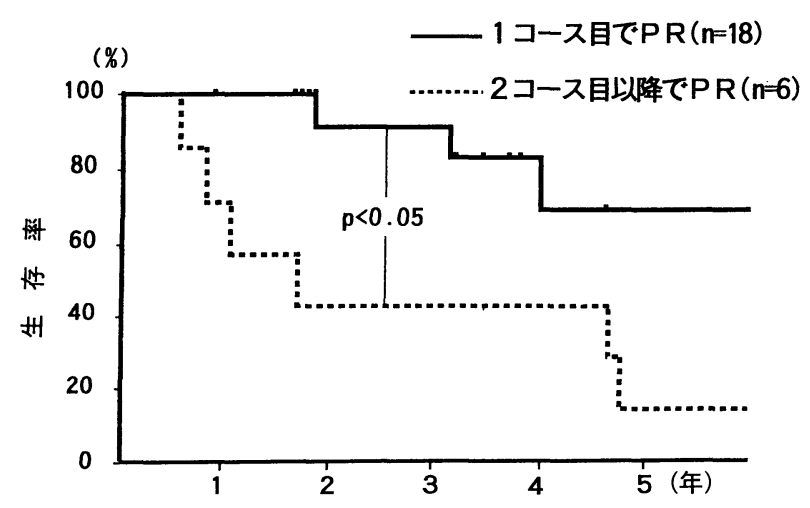

図 11 コース目で PR となった症例と 2 コース目以降で PR となった症例の生存曲線

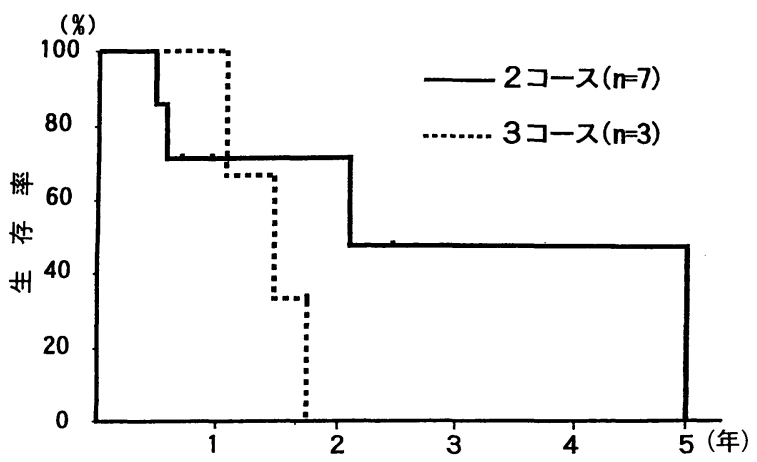

図 2 non-responder の投与回数別の生存率 $\mathrm{m}^{2}$ であったが $1000 \mathrm{mg} / \mathrm{m}^{2}$ との比較で $1000 \mathrm{mg} / \mathrm{m}^{2}$ が 有効性が高く，5-FU 投与持続時間も96時間よりも 120 時間持続の方が有効性が高いことが判明し，5-FU 1000 $\mathrm{mg} / \mathrm{m}^{2} /$ day, 120 時間持続が繁用されている7).

当初の $\mathrm{CF}$ 療法の報告では極端に高い奏効性が観察さ れていたが，その後症例数が増え，多くの施設から報告 されるに従い CR と PR を合わせた奏効性も $80 \%$ 前後, また CR 率は $20 \%$ 前後になっている。

\section{2. $\mathrm{CR}$ 療法の工夫}

通常の CDDP 先行の CF 療法は前述したようにあま り詳細な CDDP と 5-FU の相互の薬理作用の検討無し に, 臨床上のそれぞれ単独の薬剤の効果, 副作用の分散 などから併用されてきた。 そこでそれぞれの作用を解析 してみた.

(a ) 5-FU 濃度と抗腫瘍効果

in vitro で10種類の頭頸部扁平上皮癌細胞を用いて 5FU の感受性試験（24時間処理）を実施したが，0.01 $\mu \mathrm{g} / \mathrm{ml}$ から $0.1 \mu \mathrm{g} / \mathrm{ml}$ の濃度で 5 -FU に対する感受性が 認められた(図 3 )。臨床で応用する 5-FU 120時間持続 に対応して 5-FU との接触時間を延長してみたが，その 結果, $0.1 \mu \mathrm{g} / \mathrm{ml}$ で120時間接触でかららじて surviving fraction が $50 \%$ 近くになり，これらの結果から 0.1 $\mu \mathrm{g} / \mathrm{ml}$ 前後の血中濃度が得られるか否かが 5-FU の頭頸 部扁平上皮癌への殺細胞効果を示す critical dose と考兄 られた。ちなみに大腸癌などの消化器腺癌では， 0.05

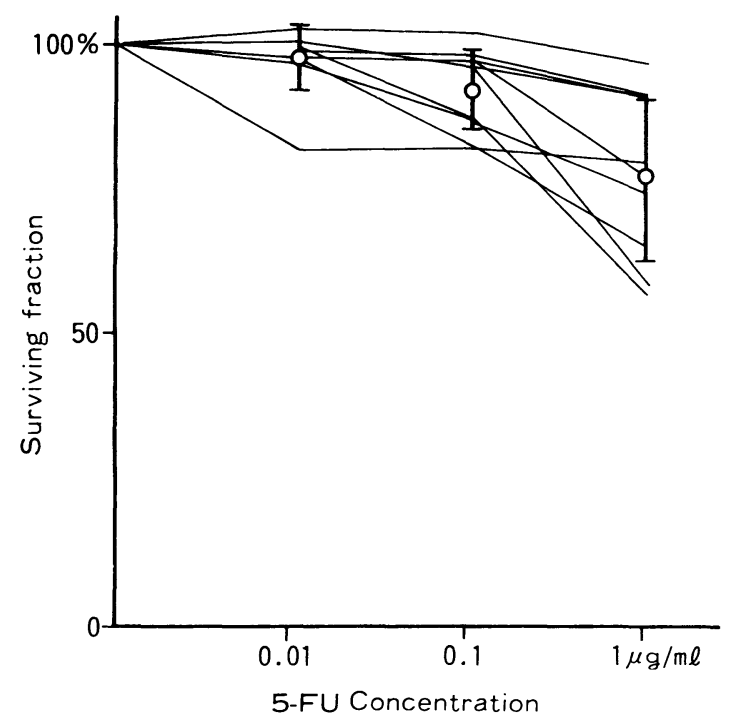

図 3 頭頸部癌培養細胞10種の 5-FU 感受性 
$\mu \mathrm{g} / \mathrm{ml}$ と頭頸部扁平上皮癌の約半分の濃度で殺細胞性 を示すことが知られている．そこで $5-\mathrm{FU} 1000 \mathrm{mg} / \mathrm{m}^{2}$ /day 120 時間持続静注 3 例の血中濃度を 5-FU 開始 3 日 目の $\mathrm{AM} 6: 00, \mathrm{PM} 6: 00$ と測定してみた. AM $6: 00$ にはそれぞれ 0.085, 0.126, $0.192 \mu \mathrm{g} / \mathrm{ml}, \mathrm{PM} 6: 00$ に は $0.112,0.187,0.262 \mu \mathrm{g} / \mathrm{ml}$ と少なくとも $0.1 \mu \mathrm{g} / \mathrm{ml}$ は超光，かつPM 6：00 の方がやや 5-FU 血中濃度が高 かった。この 3 例は 5-FU 単剤でいずれも PR を示して いた．従来より 5-FU 持続投与でも5-FU 血中濃度には 日内変動があることが知られている8) 11). 最近 Vokes ら9) は $5-\mathrm{FU} 640 \mathrm{mg} / \mathrm{m}^{2} / \mathrm{day}$ を120時間持続しわれわれ と同様に PM の方が $\mathrm{AM}$ より 5-FU 濃度が高く, CR が 得られた症例の 5-FU 濃度が高かったことを報告してい る. しかし一方で, 5-FU 血中濃度の高い症例では副作 用の多いことも判明している.

(b) CDDP と 5-FU の併用効果

つぎに，CDDP と5-FU の併用効果について検討し た12)。それぞれの薬剤単独, 併用で24時間処理した結 果を見ると，CDDP 単独 $(1 \mu \mathrm{g} / \mathrm{ml})$ では73\%，5-FU 単 独 $(10 \mu \mathrm{g} / \mathrm{ml})$ で39\%, この処理量の両薬剂で併用処理 すると $20 \%$ ，それぞれ半量づつ併用すると $39 \%$ であり， interaction index から見ると相乗効果が認められた(図 $4)^{12)}$.ささら CDDP と 5-FU の投与のタイミングを検 索するため通常の CF 療法で臨床に応用されている CDDP から 5-FU 処理, その逆の 5-FU から CDDP 処 理, また同時処理に分けて検討した（図 5 ). ${ }^{3} \mathrm{H}-\mathrm{TdR}$ uptake 法, メチレンブルー法ともに CDDP 先行処理, 同 時処理, 5-FU 先行処理の順に抗腫瘍性が高まることが

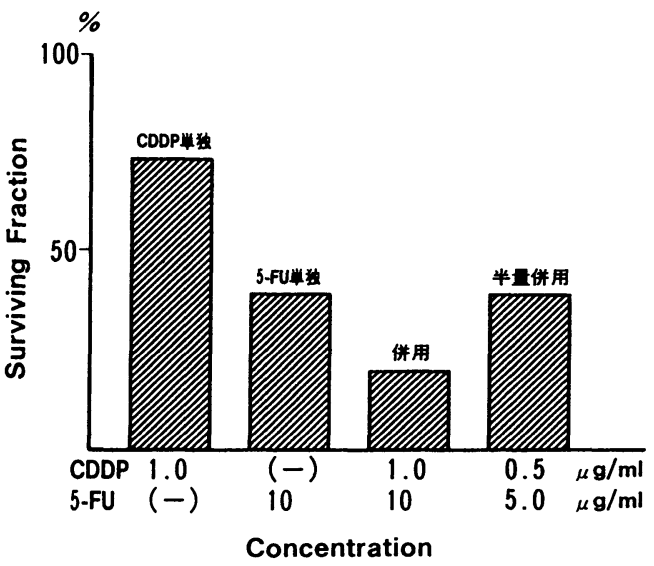

図 4 CDDP，5-FU 併用感受性試験12)

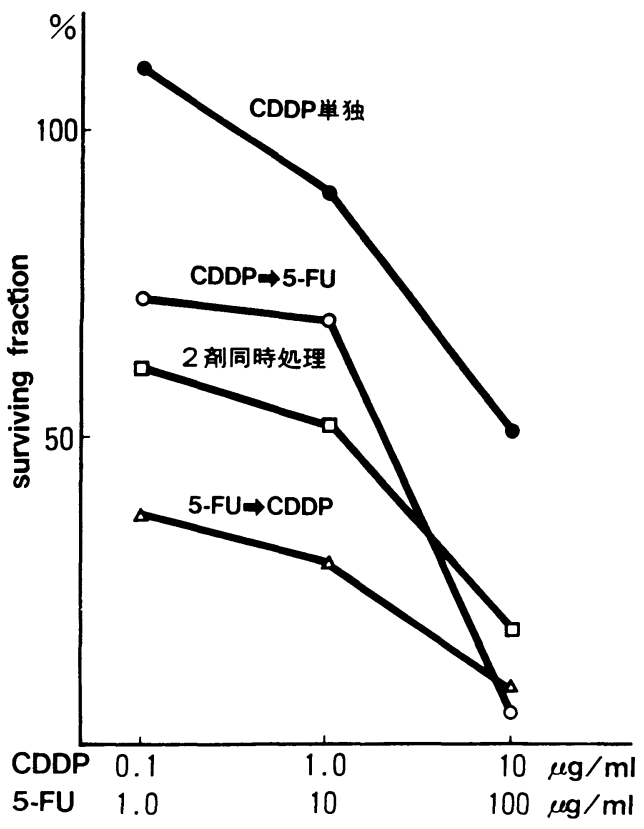

図 5 CDDP，5-FU 併用処理順による感受性試験

観察された.

この 5-FU 先行処理が抗腫瘍性が高いことの機序を, BrdU 法を用いた cell cycle から検討した．培着開始72 時間後の対照群と比較し, 培養終了前 24 時間 CDDP と 接触させた細胞群は $\mathrm{S}$ 期， $\mathrm{G} 2 / \mathrm{M}$ 期に，また 5-FU で処 理した細胞群は $\mathrm{G} 0 / \mathrm{G} 1$ 期への強い集積が認められた。 一方併用処理した細胞群では, CDDP で24時間処理後 に 5-FUで処理したときには対照群との間に大きな相違 は見られなかった．これに対して 5-FU 処理後に CDDP 処理した場合は, CDDP 処理後もさらに 5-FU の影響と 考えられる G2/G1 期への進行が進んでいた。この結果 から 5-FU 先行, その後に CDDP 処理の抗腫瘍性が高

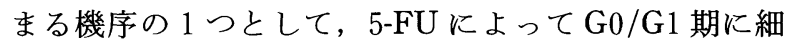
胞が集積し, 主に G1 期に殺細胞性 (cytocydal) に働く CDDP がこの集積した $\mathrm{G} 1$ 期細胞に強く影響したものと 考えられた.

一方, Etienne ら ${ }^{13)}$ は逆に CDDP 先行処理の方が 5FU 先行処理よりも抗腫瘍結果が高いことを指摘してい る. しかし，5-FU が持続で入る頭頸部癌での CDDP と 5-FU 併用療法の用い方を考慮すると， 5-FU を先行し， その途中に CDDP を投与することはわれわれと Etienne らの結果の両者の利点を用いることになる。そこで5- 
$\mathrm{FU} 1000 \mathrm{mg} / \mathrm{m}^{2} /$ day 5 日間持続点滴し, その 4 日目 にCDDP $60 \mathrm{mg} / \mathrm{m}^{2}$ を入れる $\mathrm{CF}$ 療法变法を施行し, 通 常の CF 療法と比較した. その結果, 通常の CF 療法と 比較して有意差はないものの奏効率, CR 率ともに 5FU 持続投与中に CDDPを投与した方が治療成績が高 い傾向が観察された(図 6 ).

（c）CDDP，5-FU に新たに加光る薬剤の選択

CDDP と 5-FU にほかの制癌剤を加えた場合の感受性 試験を行い(14)，臨床への応用を試みた。 CDDP と 5-FU の濃度は追加する一剤の併用効果を明らかにする目的で, $\mathrm{CDDP}$ と 5-FU の濃度を低濃度の CDDP $0.005 \mu \mathrm{g} / \mathrm{ml}$, 5-FU $0.05 \mu \mathrm{g} / \mathrm{ml}$ とした。 また加えるも5 1 剂の各濃度 は，臨床投与量の $1 / 10 ， 1 / 100$ として検討した. 用いた 頭頸部扁平上皮癌細胞株は11種類で，それぞれの細胞の 感受性の平均值を surviving fractionから求めた。 $\mathrm{CDDP}$ と 5-FU に加える薬剤として adriamycin (ADM), etoposide (ETOP), peplomycin (PEP), methotorexate (MTX), cyclophosphamide (CPM), vincristine (VCR) を 検討した(図 7 )。結果は, CDDP と 5-FU のみでは surviving fractionは94\%に保たれていた。それぞれの薬剤 の抗腫瘍性と比較して $0.01 \mu \mathrm{g} / \mathrm{ml}$ の濃度の ETOP, MTX で $(\mathrm{p}<0.05)$ ，またPLM で有意差が観察された $(\mathrm{p}<0.01)$.さらに CDDP，5-FU の濃度をそれぞれ 0.01 $\mu \mathrm{g} / \mathrm{ml}, \quad 0.1 \mu \mathrm{g} / \mathrm{ml}$ と高くしてCY，VCR を先行させて 感受性を検討した. 若干感受性の上昇は観察されたが, 有意差はなかった。

これらの薬剤の副作用は CDDP，5-FU と比較的共通 しないため, $\mathrm{CPM}\left(400 \mathrm{mg} / \mathrm{m}^{2}\right), \mathrm{VCR}\left(1 \mathrm{mg} / \mathrm{m}^{2}\right)$ を $\mathrm{CF}$ 療法に加えてそれぞれ10例，5例の未治療進行頭頸部扁

\section{CDDP先行 $(\mathbf{N}=60)$}

\begin{tabular}{|c|c|c|}
\hline & & \\
\hline CR & PR & NC or PD \\
\hline
\end{tabular}

\section{5-FU先行 $(\mathbf{N}=70)$}

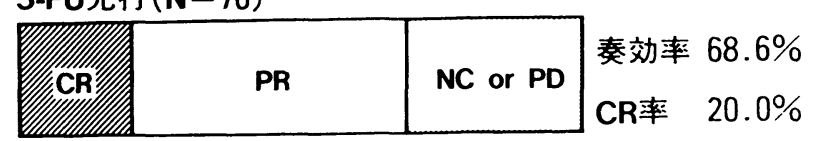

\begin{tabular}{lllll}
\hline & 1 & & \\
\hline & 25 & 50 & 75 & $100 \%$
\end{tabular}

図 6 通常の CF 療法と CF 療法変法の有効性の比較

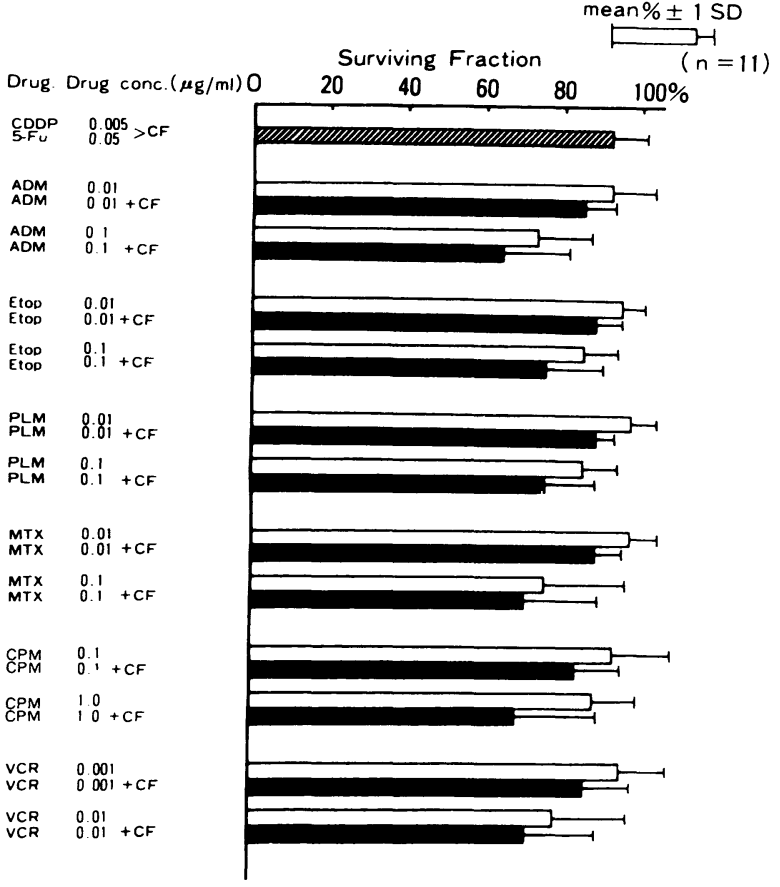

図 7 CDDP，5-FU に新たに加える薬剤の選択

平上皮癌症例に臨床応用したが奏効性は通常の CF 療法 と変わりなかった。ちなみにCF 療法に BLM を加えた Recondo ら ${ }^{15)}$ の再発あるいは転移癌での検討でも BLM を加えても CDDP と vindesine 併用に比較して有効性 は低く, Perey ら 16) の報告では CF 療法に vindesineを 加えても高い奏効率， CR 率は得られていない.

つぎに新たに加える薬剤として MTXを選択した ${ }^{17) .}$ CDDP， 5-FU， MTXの投与順を決定するために， MTX と 5-FU の処理順を変えて感受性試験を試みた (図 8 ) ${ }^{17)}$. ちなみにそれぞれの薬剤の濃度は, 臨床投与 量の最高血中濃度の $1 / 100$ とした. MTX を5-FU 処理 前に先行処理した群では各単剤処理群と比較して抗腫瘍 効果の増強が認められたが, MTXを5-FUより後に処 理した群では逆に抗腫瘍効果は抑制された。

一方, leucovorin (LV) は 5-FU の modulator として 知られ，その機序は還元型葉酸を供給することにある. そこでLV と 5-FU の併用に抲ける投与のタイミングと 各々の薬剤の濃度の違いによる感受性を比較した(図 $9)^{17)}$. LV 単独処理群では抗腫瘍効果は認めなかった が，5-FU との併用添加処理群で 5-FU 濃度が高いほど 抗腫瘍効果が高かった。しかし，LVの濃度に依存せず 


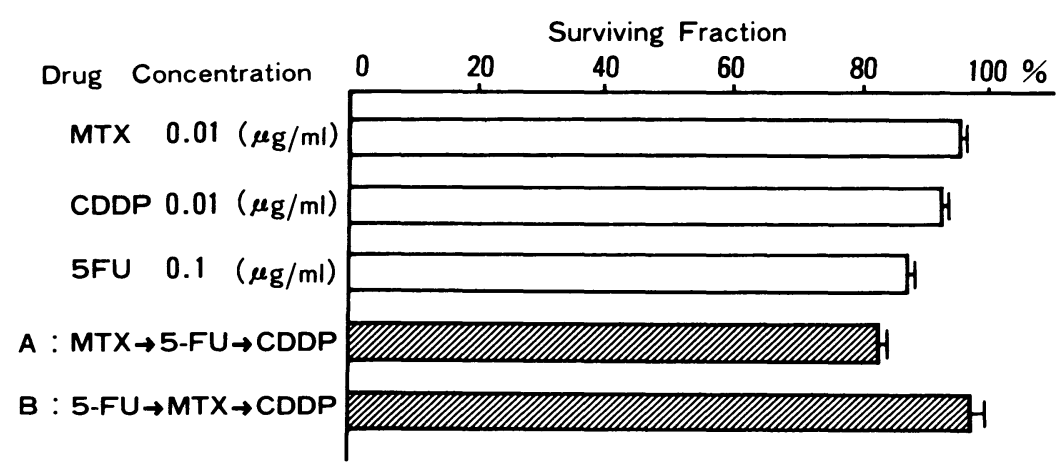

図 8 MTX 併用の投与順による感受性試験結果 ${ }^{17)}$

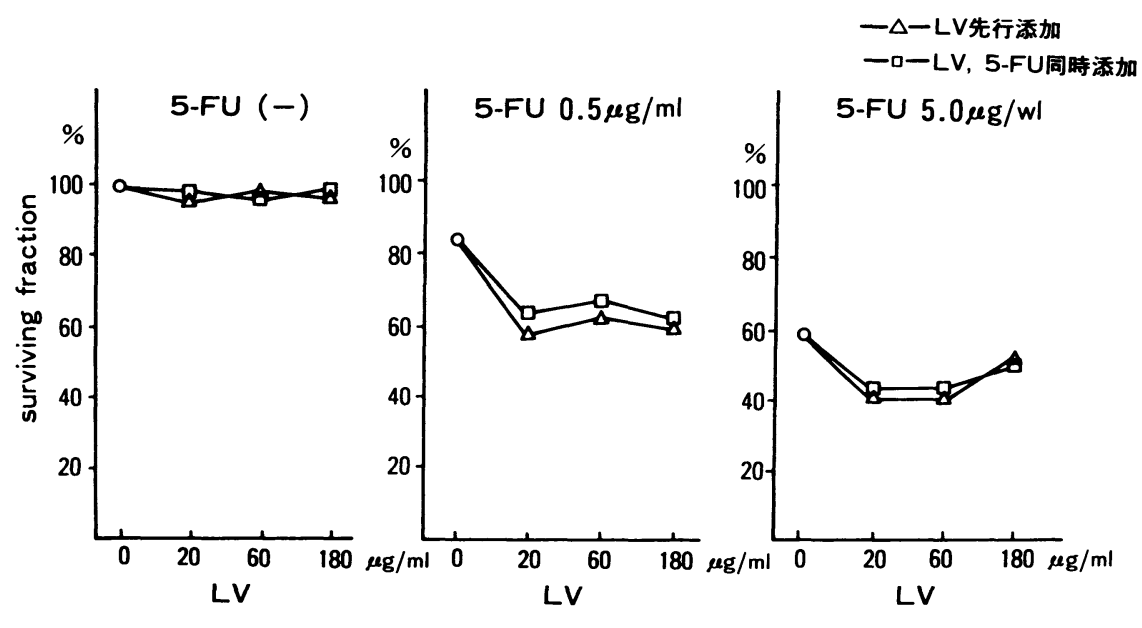

図 9 5-FU と LV 併用の感受性試験 ${ }^{17)}$

併用効果を認め，またLVの併用添加のタイミングにも 影響を受けなかった。

LVを 5-FU の modulator として用いる場合は LV の 投与量が問題となる. Etienne ら ${ }^{13)}$ は 5-FU の抗腫瘍効 果は LV 濃度が上昇するに従って増強することを観察し ている. 一方，LVの量に関してはin vitro で検索した O'Connel ら ${ }^{18)}$ は FdUMPによる thymidine symthetase (TS) の阻害とその持続に必要な LV の濃度は $10 \mu \mathrm{M}$ 以 上必要であるが，5-FU が持続的に投与される場合は 1 $\mu \mathrm{M}$ で十分であることを報告している.ささらに進行した 大腸癌に臨床応用 L, LV $20 \mathrm{mg} / \mathrm{m}^{2}$ あるいは LV 200 $\mathrm{mg} / \mathrm{m}^{2}$ の i.v. bolus に加えて 5-FU $300 \mathrm{mg} / \mathrm{m}^{2} 5$ 日間 持続を併用した結果では，予後に差がなくかつLV 20 $\mathrm{mg} / \mathrm{m}^{2}$ の方が奏効率が良いことから LV は低濃度で 5 FUに対する十分な modulator の効果が観察されている.
既に頭頸部扁平上皮癌症例でも high dose の LV と CDDP，5-FU の有用性は1990年代前半に指摘されてい

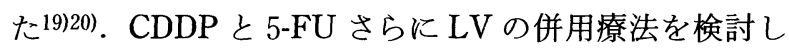
た最近の報告で, Chi $5^{21)}$ は上咽頭癌を対象に未治療新 鮮癌あるいは局所再発20例で CR 15\%, PR 85\%, 遠隔 転移15例でも CR 13\%, PR 68\%と高い奏効性を観察し ている。また通常の CF 療法に近いCDDP と 5-FU の 投与方法 (CDDP $100 \mathrm{mg} / \mathrm{m}^{2}, 5-\mathrm{FU} 500 \mathrm{mg} / \mathrm{m}^{2} /$ day $\times 5$ 日間持続)に LV 大量持続療法 $\left(200 \mathrm{mg} / \mathrm{m}^{2} / \mathrm{day}\right)$ を加味 したSchneider ら ${ }^{11)}$ の報告では33例中, 原発臓器に関 して CR 64\%，PR 24\%また局所リンパ節で CR 41\%， PR 37\% と極めて CR 率の高い結果が得られている.さ らに効果の指標として, 血中の 5-FU 濃度と全葉酸濃度 が相関することも観察されている.

以上の結果をふまえて, それぞれの薬剤の modulator 
すなわち，CDDP と 5-FU，5-FU と MTX，5-FU と LV の相互作用を期待し，現在われわれの施設ではこれらの 4 薬剂を併用した治療法を臨床に応用している(表 1 )。 その結果，確かに CDDP 先行の CF 療法，5-FU を先行 する modified CF 療法よりも modulatorを利用したこ の 4 剂併用は CR 率が高いことが観察された(図10).

（d） Interferon- $\alpha$ (IFN- $\alpha$ )を併用した CF 療法

最近はその相乗効果に疑問がなげかけられているが， IFN- $\alpha$ と 5 -FU との併用効果を期待し， CF 療法にさら にIFN- $\alpha$ を加光た化学療法が頭頸部扁平上皮癌に対し て米国を中心に行われている.IFN の作用機序として 様々な説が考えられている2223)．5-FU の抗腫瘍性を thymidine uptake や thymidine kinase 活性を下げて, あるいは FdUMP 形成を増加させて増強する。あるい は thymidine synthetase 阻害の過程を増強，あるいは その阻害の持続時間を延長する，あるいは細胞回転に影 響して 5-FUの効果を強めることなどである。また IFN の CDDP の抗腫瘍性増強作用としては IFN 処理に よって腫瘍細胞内の白金錯体の濃度が上昇することが判 明しているが，その詳細な機序についてはまだ十分には 解明されていない。

そこでわれわれも IFN- $\alpha$ に対する感受性試験を KB 細胞を用いて検討した(図11)。臨床に用いる IFN- $\alpha$ 投 与で十分にこの血中濃度が得られる $100 \mathrm{U} / \mathrm{ml}, 1000$ $\mathrm{U} / \mathrm{ml}$ また $5-\mathrm{FU}(10 \mu \mathrm{g} / \mathrm{ml})$ でのそれぞれの単独処理の 抗腫瘍性と比較し, 確かに両薬剤で併用処理すると抗腫 瘍性は増強していた。ただし，併用での抗腫瘍性も5-
FU で先行処理すると減弱することが観察された。また CDDP と 5-FU 処理に IFN- $\alpha$ を添加することによって, IFN- $\alpha$ 濃度依存性に抗腫瘍効果が増強することも観察さ れた(図12).

最近 CDDP，5-FU と IFN- $\alpha$ を併用した米国の Southwest Oncology group の結果では24) 化学療法を受けてい ない50例の再発あるいは遠隔転移例で 3 例 ( $6 \%$ ) の CR と 5 例 (10\%)の PR を観察している. しかしこうした再 発例では CDDP と 5-FU のみの臨床効果と比較して必 ずしも奏効性で優れているとは言えず，INF- $\alpha$ を加える ことによって血液毒性, 消化器症状の副作用が増強する このレジメの有用性には否定的な見解が述べられている.

一方 Chicago 大学のグループは CDDP, 5-FU, LV に さらに IFN- $\alpha$ を加えた治療を考案し臨床に応用してい る9225)26). 当初は $5-\mathrm{FU} は 640$ あるいは $800 \mathrm{mg} / \mathrm{m}^{2} /$ day の 5 日間連日投与であり, LV も $100 \mathrm{mg}$ の経口を 36 回, IFN- $\alpha$ も 0.5 から $4.0 \times 10^{6} \mathrm{U} / \mathrm{m}^{2} /$ day であった。 その後 臨床で検討した抗腫瘍効果, 副作用から，5-FU，LV, IFN- $\alpha$ の量が変更された。すなわち $5-\mathrm{FU}$ は $640 \mathrm{mg} / \mathrm{m}^{2}$ /day の 5 日間連続， $\mathrm{LV}$ は $300 \mathrm{mg} / \mathrm{m}^{2} /$ day の 132 時間

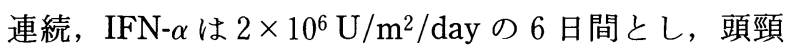
部進行癌の induction chemotherapy として用いられた 結果が最近報告されている9)。これによると89例 (86例 が stage N)に 3 コース用いられ，3 例の化学療法死は あるものの，66\%と驚異的な $\mathrm{CR}$ 率が見られている。 $\mathrm{CR}$ 例では $\mathrm{CR}$ 以外の症例と比較して，5-FU の最高血 中濃度が高く, また骨䯣抑制, 口内炎の副作用も5-FU
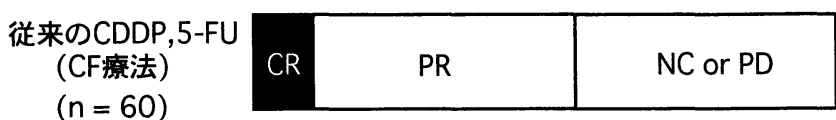

奏効率 $58 \%$

C R率 10\%
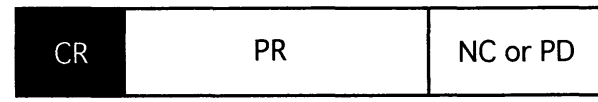

奏効率 $69 \%$

$(n=70)$

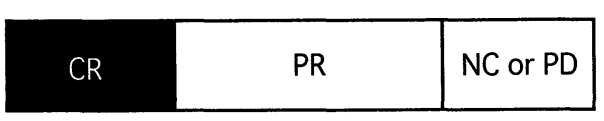

奏効率 $74 \%$

C R 率 $30 \%$

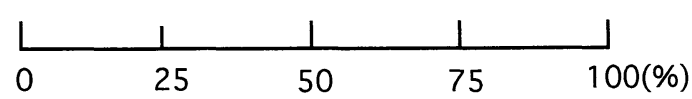

図10 CF 療法の工夫による奏効率の比較 


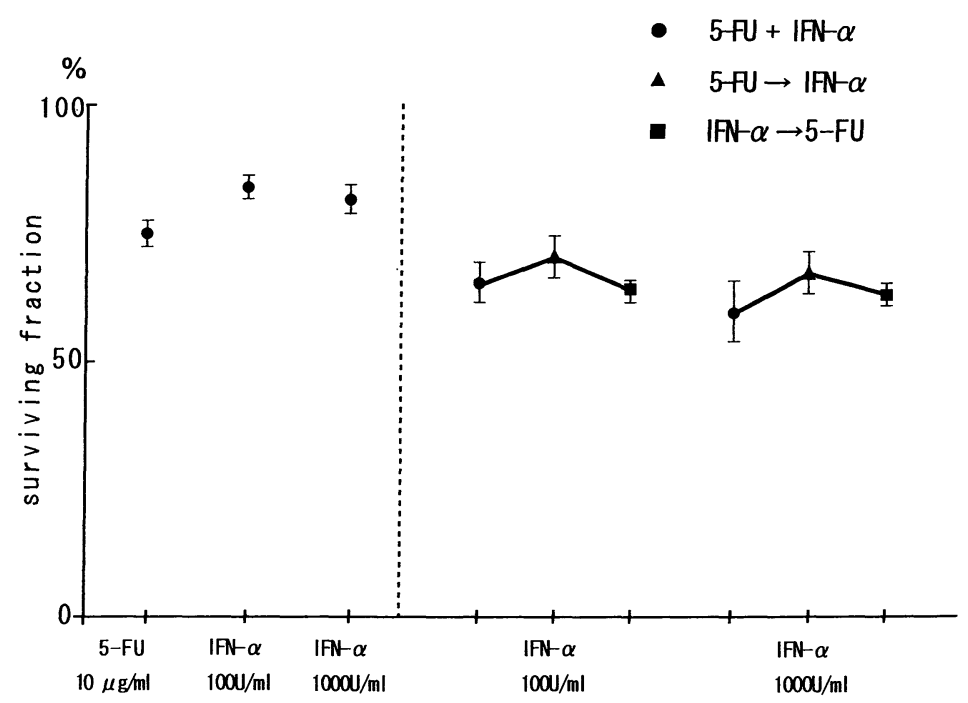

図11 5-FU と IFN- $\alpha$ 併用による感受性試験

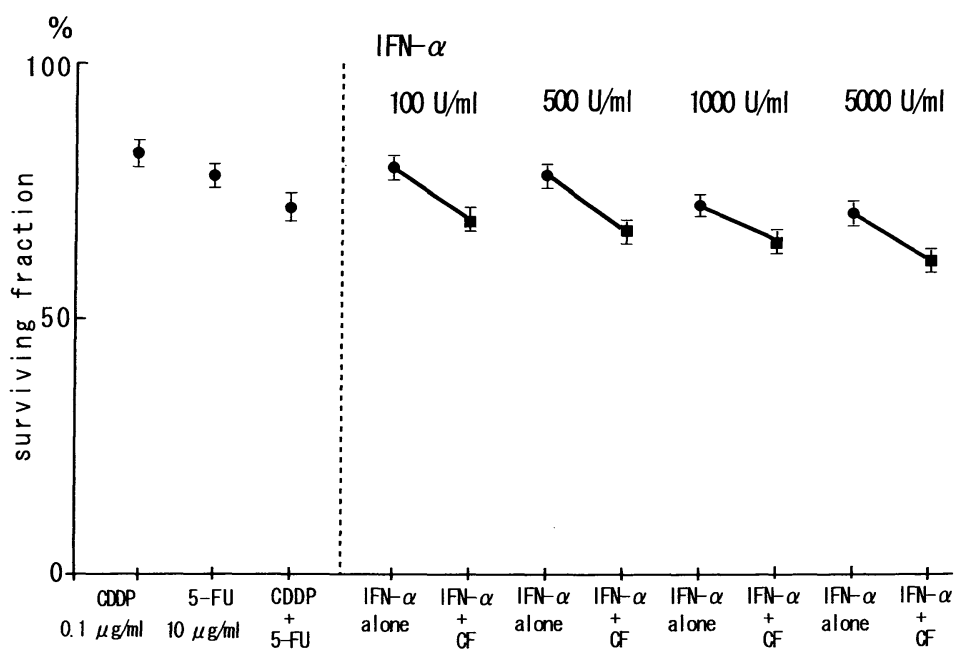

図12 CDDP，5-FU と IFN- $\alpha$ の併用による感受性試験

血中濃度と相関していた.さらに同じグループの以前の 報告ではこの組合せの induction chemotherapy 後, 増 感剂を用いた強力な放射線治療によって高い局所制御率, 遠隔転移制御率さらに良好な生存率が得られている26).

\section{CDDP 以外の白金錯体の検討}

現在臨床に応用されている CDDP, CBDCA, 254-S の in vitro, in vivo での頭頸部扁平上皮癌飞対する抗腫瘍性 を検討した(図13) 27)。なお NK121，DWA2114R は開発 段階で使用が中止された白金錯体である。in vitro では その抗腫瘍性は CBDCA， 254-S, CDDP の順に強く， CDDP と同等の抗腫瘍性をCBDCA で得るには20〜30 倍量, また254-S でも 3 倍量近く必要と考えられた。一 方, in vivoでヌードマウスに腫瘍を移植後マウスで検 討された LD50の $1 / 3$ 量である CDDP $5 \mathrm{mg} / \mathrm{kg}, \mathrm{CBDCA}$ $50 \mathrm{mg} / \mathrm{kg} ， 254-\mathrm{S} 5 \mathrm{mg} / \mathrm{kg}$ を腹腔内投与した結果も in vitro と同様であった(図14) ${ }^{27)}$. 現在臨床で使用されて いる CDDPは $60 \sim 100 \mathrm{mg} / \mathrm{m}^{2}, \mathrm{CBDCA}$ は $400 \mathrm{mg} / \mathrm{m}^{2}$, 
Cell: KB

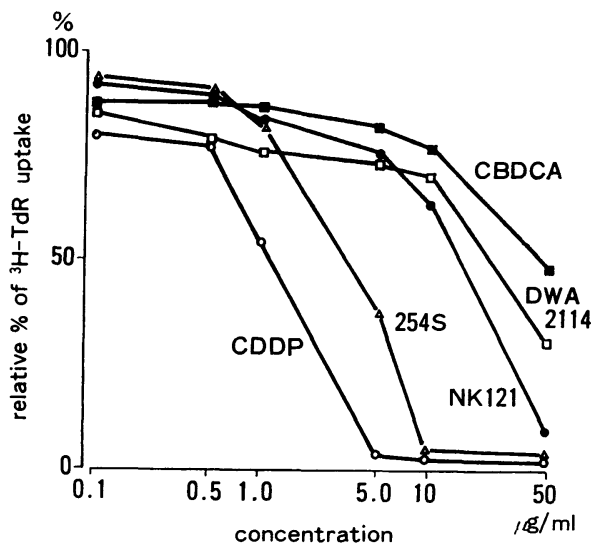

Cell : NPC-TY861

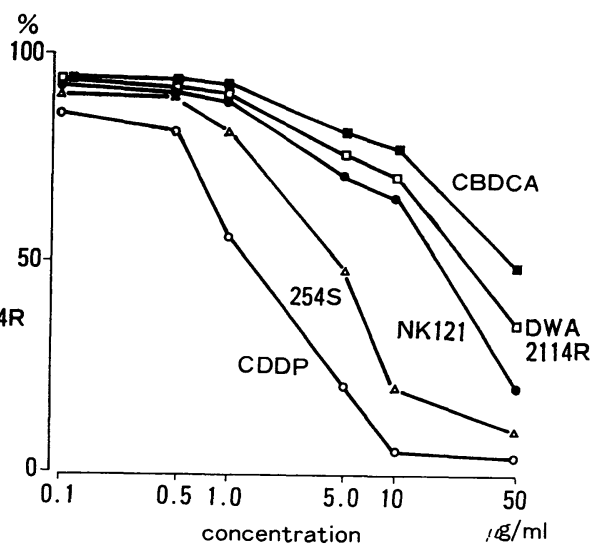

図13各種白金錯体による in vitro 感受性試験 ${ }^{27)}$
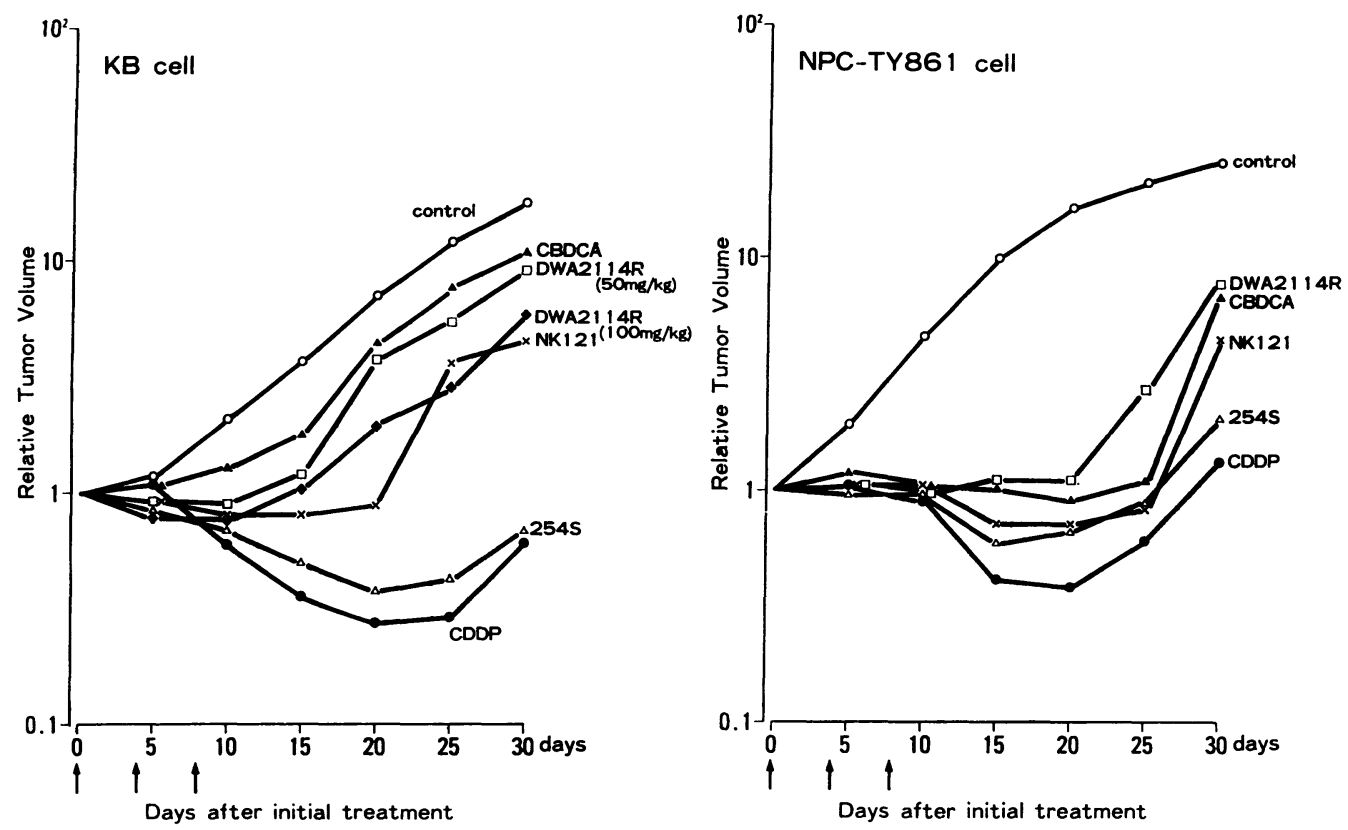

図14 各種白金錯体によるin vivo 感受性試験 ${ }^{27)}$

254-S は $100 \mathrm{mg} / \mathrm{m}^{2}$ でありこの投与量では少なくとも in vitro, in vivo の結果から判断すると CDDP と同等あ るいはそれ以上の抗腫瘍効果をこれらの白金錯体に期待 するのは無理ではないかと考えられ，併用する薬阂の選 択が問題となる.

\section{3．新しい制癌剤の感受性試験}

本邦では頭頸部癌には適応が無いが，topoisomerase
I を抑制し細胞の DNA 障害によって抗腫瘍性を現す CPT-11 ๖ CDDP 後の新しい制癌剤として臨床に応用 されている.この topoisomerase I 阻害剤はADM，5FUなどの耐性株にも有効と考えられている28). 頭頸部 癌では topoisomerase I の活性が正常細胞の60倍近く に立進していることもあり 29)，この薬剤の抗腫瘍性も注 目されるところである.CPT-11 はその主代謝産物であ る SN-38 が高い抗腫瘍性を持つ。そこで SN-38を用い 


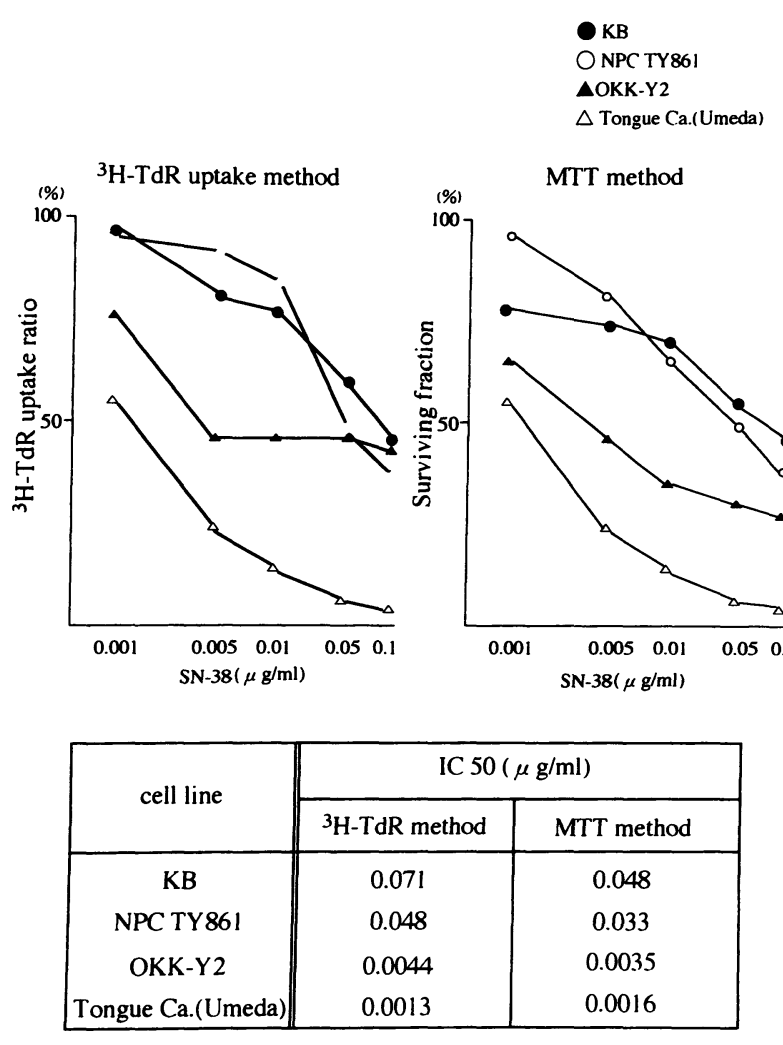

図15 頭頸部癌細胞の SN-38 に対する感受性

て 4 種類の頭頸部癌細胞の感受性試験を行った (24時間 処理, 図15).3H-TdR uptake 法, MTT 法でほぼ同じ 結果を得，その IC50は $0.1 \mu \mathrm{g} / \mathrm{ml}$ 末満であった。 また $\mathrm{SN}-38$ は CDDP との相乗作用が最近報告されている30). そこで低濃度での CDDP，5-FU 処理に SN-38 を加えた が，わずかに併用効果が認められるものの有意差は観察 されなかった(図16). SN-38 と 5-FU は臨床的にも相乗 作用を示さず，大腸癌症例では CPT-11 単剤の方が 5FU とCPT-11 併用より有効性が高く，これは 5-FU が CPT-11 から SN-38 への変換を阻害するためと考えられ ている31).これらの結果から推察すると CPT-11を CF 療法に加えてより強い抗腫瘍性は期待できない可能性が 高い.

一方細胞内の microtubule を安定化させ, G2/M 期で 細胞塊点をブロックし, DNA 合成阻害によって抗腫瘍 性を発揮する paclitaxel ${ }^{32)}$ あいは docetaxel ${ }^{33)}$ も新し い制癌剤として注目されている. docetaxel は米国や本 邦で phase II の臨床研究が進んでいる. 根治不可能な 進行癌や再発扁平上皮癌を対象とした米国での docetax-
(MTT method)

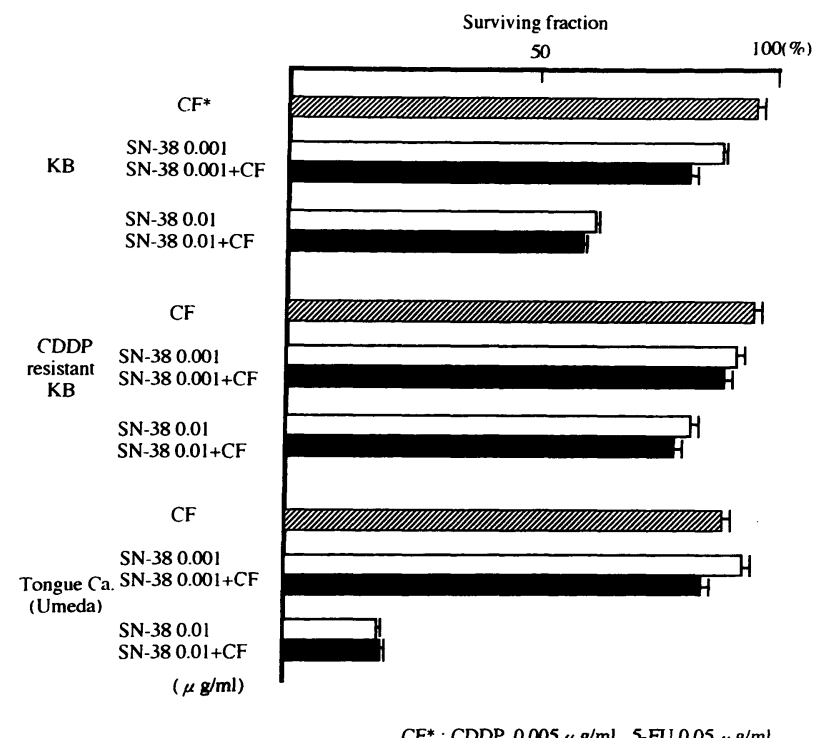

図16 CDDP，5-FU と SN-38 併用同時処理の感受性

el 単独での報告では ${ }^{33)} 31$ 例中 4 例 $(13 \%)$ KR, 9 例 (29\%)にPR が観察されている，そこで paclitaxel を用 いて頭頸部癌細胞の感受性を検討した。この薬剤の濃度 を変えて 1 時間， 4 時間処理したが 1 時間処理でも 5 $\mu \mathrm{g} / \mathrm{ml}, 4$ 時間処理で $0.5 \mu \mathrm{g} / \mathrm{ml}$ で抗腫瘍効果を認めた （図17）. 頭頸部癌を用いて検討した Gan ら ${ }^{32)}$ も BrdU 取り込みから paclitaxel 24時間処理の抗腫瘍性を検討し, この処理時間での阻害効果は $1 \mu \mathrm{M}$ で maximum になる ことを報告している。ちなみに paclitaxel の $1 \mu \mathrm{M}$ は $0.85 \mu \mathrm{g} / \mathrm{ml}$ でほぼわれわれの 4 時間処理での抗腫瘍性 出始める濃度に近いものであった。またこの報告では paclitaxel の抗腫瘍性は腫瘍細胞の制癌剂耐性に関与す る遺伝子産物の p-glycoprotein 発現と相関することも指 摘している.

さらに CDDP $(0.005 \mu \mathrm{g} / \mathrm{ml}), 5-\mathrm{FU}(0.05 \mu \mathrm{g} / \mathrm{ml})$ と低 濃度に設定し, paclitaxel $0.001 \mu \mathrm{g} / \mathrm{ml}, 0.05 \mu \mathrm{g} / \mathrm{ml}$ と 24時間同時処理での併用効果を検討した（図18). 前述し た 4 時間処理と比較すると paclitaxel はこの濃度でも単 独で抗腫瘍性が認められ，かつこの低濃度の CDDP，5FU 処理との併用で抗腫瘍性が増強していた.

paclitaxel や docetaxel は CDDP と交叉耐性を持た ず34), CDDP との併用効果も他の癌種では観察されて いる35)36)。われわれの今日の検討でも $0.3 \mu \mathrm{g}$ の CDDP 

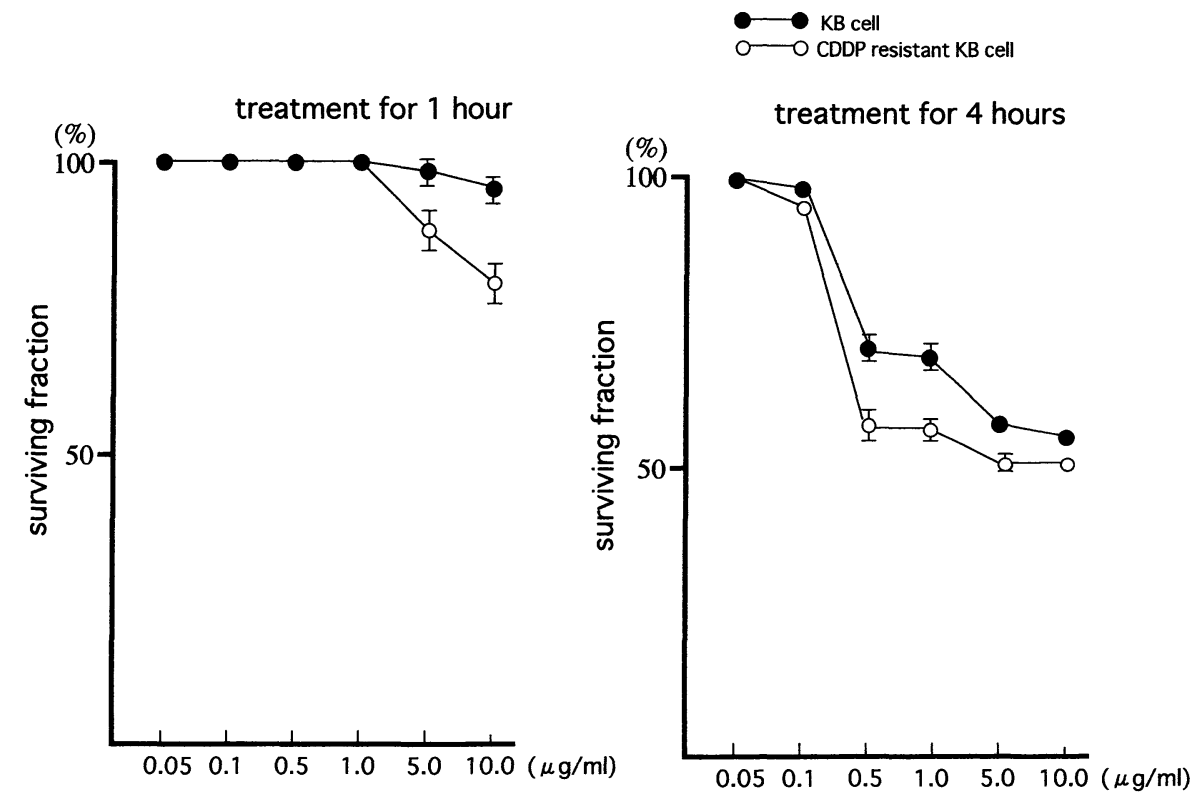

図17 paclitaxelに対する感受性試験

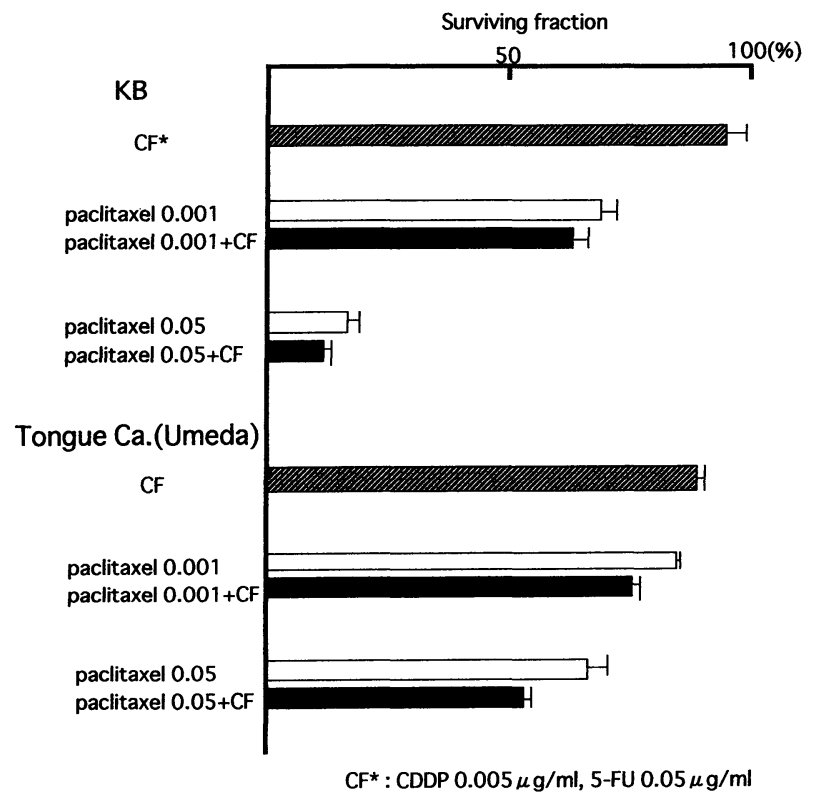

図18 CDDP, 5-FU, paclitaxel に対する感受性試験

に耐性となった $\mathrm{KB}$ 細胞は親株の $\mathrm{KB}$ 細胞よりも paclitaxelに対してょり感受性を認めた. 今後 CDDP が効果 のない症例には有用な薬剤ではないかと考えている，し かしCDDPとの併用では paclitaxelを先行させた方が
より強い抗腫瘍性を示すことが報告されて括り, 現在検 討中である.

以上, CDDP と 5-FU 併用療法を中心に頭頸部扁平上 皮癌に対する化学療法を概説した. 確かにCDDPを含 む化学療法は予後の向上にいくらか貢献することが判明 しつつある26)37). しかしながら多くの頭頸部進行癌の予 後は根治療法の的確性にまだ依存しているのが現状であ る.

neo-adjuvant chemotherapy 後に根治治療として拡大 手術を用いず放射線治療によって藏器温存を図った試験 も行われ, 上顎洞癌3), 喉頭癌38) 40) では生存率を低下 させることはなく, 臓器温存率が高いと報告されている. しかし他の臓器ではいまだに臓器温存が図れるか否かの 結論は出ていない41). 予後を低下させることなく蔵器の 温存を可能にするには, 放射線治療の効果を増強する新 たな化学療法の考案も $\mathrm{CR}$ 率の高い強力な化学療法の案 出とともに今後の課題といえる.

\section{参考文献}

1) Al-Kourainy K, Kish J, Ensley J, et al : Achievement of superior survival for histologically negative versus histologically positive clinically complete responders to cisplatin combination in patients with locally advanced 
head and neck cancer. Cancer $59: 233 \sim 238,1987$.

2 ) Rooney M, Kish J, Jacobs J, et al : Improved complete response rate and survival in advanced head and neck cancer after three-course induction therapy with 120-hour 5-FU infusion and cisplatin. Cancer $55: 1123 \sim 1128,1985$.

3 ) 犬山征夫, 福田 諭, 藤井正人: 特集 生存からみた癌化 学療法の進歩 II 頭頸部癌. 癌と化学療法 $22: 732 \sim 738$, 1995.

4 ) Tsukuda M, Mochimatsu I, Kokatu T, et al : Induction chemotherapy in advanced head and neck cancer. Auris Nasus Larynx 21 : 186 192, 1994.

5 ) Tsukuda M, Kokatu T, Ito K, et al : Chemotherapy for recurrent adeno and adenoidcystic carcinomas in the head and neck. J Cancer Res Clin Oncol $119:$ 756 758, 1993.

6 ) Johnson JT, Mayernik DG, Myers EN, et al : Cisplatin-5fluorouracil chemotherapy for advanced inoperable squamous carcinoma of the head and neck. Head Neck Surgery $9: 336 \sim 340,1987$.

7 ) Decker DA, Drelichman A, Jacobs J, et al : Adjuvant chemotherapy with cis-diamminodichloroplatinum II and 120-hour infusion 5-fluorouracil in stage III and $\mathrm{N}$ squamous cell carcinoma of the head and neck. Cancer $51:$ 1353 1355, 1983.

8 ) Petit E, Milana G, Levi F, et al : Circadian rhythm-varying plasma concentration of 5 -fluorouracil during a five-days continuous venous infusion at a constant rate in cancer patients. Cancer Res $48:$ 1676 1679, 1988.

9 ) Vokes EE, Mick R, Kies MS, et al : Pharmacodynamics of fluorouracil-based induction chemotherapy in advanced head and neck cancer. J Clin Oncol $14: 1663 \sim 1671,1996$.

10) Milano G, Etienne MC, Renee N, et al : Relationship between fluorouracil systemic exposure and tumor response and patient survival. J Clin Oncol 12 : 1291 1295, 1994.

11) Schneider M, Etienne MC, Milano G, et al : Phase II trial of cisplatin, fluorouracil, and pure folic acid for locally advanced head and neck cancer; a pharmacokinetic and clinical study. J Clin Oncol $13: 1656 \sim 1662,1995$.

12）古川 滋 : 頭頸部扁平上皮癌に対する CDDP，5-FU 併用 療法の検討. 横浜医学 $43: 55 \sim 70,1992$.

13) Etienne MC, Bernard JL, Formento FP, et al : Dose reduction without loss of efficacy for 5 -fluorouracil and cisplatin combined with folinic acid; in vitro study on human head and neck carcinoma cell lines. Br J Cancer $63: 372 \sim 377$, 1991.

14）佃守, 持松いづみ, 小勝敏幸, 他 : 頭頸部癌に対する CF (CDDP，5-FU) 療法に打ける3 剂併用の基礎的検討. 癌と化学療法 $19: 553 \sim 556,1992$.

15) Recondo G, Armand JP, Domenge C, et al : Recurrent and/or metastatic head and neck squamous cell carcinoma ; a clinical, univariate and multivariate analysis of response and survival with cisplatin-based chemotherapy. Laryngoscope $101:$ 494 501, 1991.

16) Perey L, Pasche P, Bauer J, et al : Cisplatin, vindesine, and 96 -h continuous infution of 5 -fluorouracil as initial chemotherapy for locally advanced head and neck carcinoma. Am J Clin $14: 162 \sim 165,1991$.

17）小勝敏幸, 佃守, 古川 滋, 他 : 頭頸部扁平上皮癌に おける CDDP, 5-FU, MTX, LV 併用療法の検討. 耳展 39 : 49〜 55, 1996.

18) O'Connel ML : A phase III trial of 5-fluorouracil and leucovorin in the treatment of advanced corectal cancer. Cancer $63:$ 1026 1030, 1989.

19) Dreyfuss AI, Clark JR, Wright JE, et al : Continuous infusion high-dose leucovorin with 5-fluorouracil and cisplatin for untreated stage $\mathrm{N}$ carcinoma of the head and neck. Ann Int Med $112:$ 167 172, 1990.

20) Vokes EE, Schilsky RL, Weichselbaum RR, et al : Induction chemotherapy with cisplatin, fluorauracil, and highdose leucovorin for locally advanced head and neck cancer ; a clinical and pharmacologic analysis. J Clin Oncol $8: 241$ $\sim 247,1990$.

21) Chi KH, Chan WK, Cooper DL, et al : A phase II study of outpatient chemotherapy with cisplatin, 5 -fluorouracil, and leucovorin in nasopharyngeal carcinoma. Cancer $73: 247$ $\sim 252,1994$.

22) Guglielmi A, Aschele $\mathrm{C}$, Mori $\mathrm{A}$, et al : In vitro synergism between 5 -fluorouracil and natural $\beta$ interferon in human colon carcinoma cells. Clin Cancer Res $1: 1337 \sim 1344$, 1995.

23) Gupta V, Jani JP, Emerson EO, et al : Modulation of cisplatin sensitivity and accumulation by interferon $\alpha-2 \mathrm{~A}$ in human squamous carcinoma cell lines. Int J Cancer 63 : 419 422, 1995.

24) Hussain M, Benedetti J, Smith RE, et al : Evaluation of 96hour infusion fluorouracil plus cisplatin in combination with alpha interferon for patients with advanced squamous cell carcinoma of the head and neck. Cancer $76: 1233 \sim$ 1237, 1995.

25) Vokes EE, Ratain MJ, Mick R, et al : Cisplatin, fluorouracil, and leucovorin augmented by interferon alpha-2b in head and neck cancer; a clinical and pharmacologic analysis. J Clin Oncol $11: 360 \sim 368,1993$.

26) Vokes EE, Kies $M$, Haraf DJ, et al : Induction chemotherapy followed by concomotant chemoradiotherapy for advanced head and neck cancer ; impact on the natural history of the disease. J Clin Oncol $13: 876 \sim$ 
883, 1995.

27）佃守, 吉田豊一, 久保田彰, 他 : CDDP 誘導体の頭 頸部扁平上皮癌細胞株に対する抗腫瘍効果の検討. 癌と化 学療法 $15: 2811 \sim 2814,1988$.

28) Burris HA, Hanauske AR, Johnson RK, et al : Activity of topotecan, a new topoisomerase I inhibitor, against human tumor colony-forming units in vitro. J Natl Cancer Inst $84: 1816 \sim 1820,1992$.

29) Masin JS, Berger SJ, Setrakian S, et al : Topoisomerase I activity in squamous cell carcinoma of the head and neck. Laryngoscope $105: 1191 \sim 1196,1995$.

30) Fukuda M, Nishio K, Kanzawa F, et al : Synergism between cisplatin and topoisomerase I inhibitors, NB-506 and $\mathrm{SN}-38$, in human small cell lung cancer cells. Cancer Res 56 : 789 793, 1996.

31) Sasaki Y, Ohtsu A, Shimada Y, et al : Simultaneous administration of CPT-11 and fluorouracil ; alteration of the pharmacokinetics of CPT-11 and SN-38 in patients with advanced colorectal cancer. J Natl Cancer Inst 86 : 1096 1098, 1994.

32) Gan Y, Wientjes G, Schuller DE, et al : Pharmacodynamics of taxol in human head and neck tumors. Cancer Res $56:$ 2086 2093, 1996.

33) Dryfuss AI, Clark JR, Norris CM, et al : Docetaxel ; an active drug for squamous cell carcinoma of the head and neck. J Clin Oncol $14:$ 1672 1678, 1996.

34) Kelland LR and Abel G : Comparative in vitro cytotoxicity of taxol and taxotere against cisplatin-sensitive and -resistant human ovarian carcinoma cell lines. Cancer Chemother Pharmacol $30: 444 \sim 450,1992$.

35) Rowinsky EK, Citardi MJ, Noe DA, et al : Sequencedependent cytotoxic effects due to combinations of cisplatin and the antimicrotubule agents taxol and vincristine. J Cancer Res Clin Ontol $119: 727 \sim 733,1993$.

36) Vanhoefer U, Harstrik A, Wilke H, et al : Schedule-dependent antagonism of paclitaxel and cisplatin in human gastric and ovaran carcinoma cell lines in vitro. Eur $\mathrm{J}$ Cancer 31A : 92 97, 1995.

37) Merlano M, Benasso M, Corvo R, et al : Five-year update of a randomized trial of alternating radiotherapy and chemotherapy compared with radiotherapy alone in treatment of unresectable squamous cell carcinoma of the head and neck. J Natl Cancer Inst $88: 583 \sim 589,1996$.

38) The department of veterans affairs laryngeal cancer study group : Induction chemotherapy plus radiation compared surgery plus radiation in patients with advanced laryngeal cancer. N Engl J Med 324 : 1685 1690, 1991.

39) Hong WK, Lippman SM and Wolf GT : Recent advanced in head and neck cancer-Larynx preservation and cancer chemoprevention; the seventeenth annual Richard and Hinda Rosenthal foundation award lecture. Cancer Res 53 : 5113 5120, 1993.

40) Spaulding MB, Fisher SG, Wolf GT, et al : Tumor response, toxicity, and survival after neoadjuvant organpreserving chemotherapy for advanced laryngeal carcinoma. J Clin Oncol 12 : 1592 1599, 1994.

41) Urba SG, Forastiere AA, Wolf GT, et al : Intensive induction chemotherapy and radiation for organ preservation in patients with advanced resectable head and neck carcinoma. J Clin Oncol 12 : 946 953, 1994.

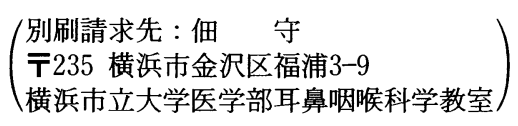

